\section{Regards sur l'économie allemande}

Bulletin économique du CIRAC

$79 \mid 2006$

Varia

\title{
Banques publiques
}

STAATS Stefan, Fusionen bei Sparkassen und Landesbanken. Eine Untersuchung zu den Möglichkeiten der Vereinigung öffentlichrechtlicher Kreditinstitute

\section{(2) OpenEdition}

Édition électronique

URL : http://journals.openedition.org/rea/459

DOI : $10.4000 /$ rea.459

ISBN : 978-2-8218-0854-6

ISSN : 1965-0787

\section{Éditeur}

CIRAC

Édition imprimée

Date de publication : 1 décembre 2006

ISSN : 1156-8992

\section{Référence électronique}

«Banques publiques », Regards sur l'économie allemande [En ligne], 79 | décembre 2006, document 2, mis en ligne le 23 avril 2008, consulté le 22 septembre 2020. URL : http://journals.openedition.org/rea/ 459 ; DOI : https://doi.org/10.4000/rea.459

Ce document a été généré automatiquement le 22 septembre 2020.

(c) CIRAC 


\section{Banques publiques}

STAATS Stefan, Fusionen bei Sparkassen und Landesbanken. Eine Untersuchung zu den Möglichkeiten der Vereinigung öffentlichrechtlicher Kreditinstitute

\section{RÉFÉRENCE}

STAATS Stefan, Fusionen bei Sparkassen und Landesbanken. Eine Untersuchung zu den Möglichkeiten der Vereinigung öffentlich-rechtlicher Kreditinstitute, Coll. Schriften zum öffentlichen Recht, vol. 1029, Duncker \& Humblot, Berlin, 2006, 324 p.

1 Les banques publiques allemandes peuvent être privatisées ; rien ne s'y oppose en droit, conclut cette thèse soutenue à l'Université Ludwig-Maximilians de Munich. L'opposition à une réforme du système à trois piliers est exclusivement et avant tout politique. (ib) 